\title{
JPEB
}

Jurnal Penelitian Ekonomi dan Bisnis, 1 (1), 2016, Hal: 1-15

http://www.jpeb.dinus.ac.id

\section{ANALISIS RANTAI NILAI (VALUE CHAIN) JAGUNG DI KECAMATAN TOROH KABUPATEN GROBOGAN}

\author{
Eka Widayat Julianto $^{1 *}$ dan Darwanto ${ }^{2}$ \\ ${ }^{1,2}$ Jurusan IESP, Fakultas Ekonomika dan Bisnis, Universitas Diponegoro \\ Jalan Prof. Soedarto SH Tembalang, Semarang 50239, Indonesia \\ *Corresponding Author: eightka.widayat@gmail.com
}

Diterima: Oktober 2015; Direvisi: Januari 2016; Dipublikasikan: Maret 2016

\begin{abstract}
Agriculture is one of the sectors has substantial contribution to Gross Domestic Product (GDP), in which one of the subsectors is seeded crops. Corn became a crop that accounts for a large enough area, One of the largest corn producer in central Java is Grobogan so corn is becoming the icon area.This study aimed to analyze Maize Value Chain in Grobogan, and formulate strategies to grow corn. The data used in this study are primary data and secondary data. This study used a descriptive statistical analysis to describe the profile of the respondents in the study area, and using Value Chain Analysis (VCA), as well as the coping strategies maize value chain using in-depth interviews (in - depth interview) with the key-person ABGC competent to corn farming development with determination key - person using purposive sampling method.
\end{abstract}

Keywords: Food Crops; Maize; Value Chain Analysis (VCA)

\section{ABSTRAK}

Pertanian menjadi salah satu sektor penyumbang terbesar untuk PDB. Salah satu subsektor yang menjadi unggulan adalah tanaman pangan. Jagung menjadi salah satu tanaman pangan yang menyumbang cukup besar, salah satu daerah yang menjadi penghasil jagung terbesar di Jawa Tengah adalah Kabupaten Grobogan sehingga jagung menjadi ikon daerah.Penelitian ini bertujuan untuk menganalisis rantai nilai jagung di Kabupaten Grobogan, serta merumuskan strategi untuk mengembangkan jagung. Data yang digunakan dalam penelitian ini berupa data primer dan data sekunder. Penelitian ini digunakan analisis statistik deskriptif untuk mendeskripsi profil responden di daerah penelitian, dan menggunakan metode Analisis Rantai Nilai (Value Chain), serta dalam strategi mengatasi masalah rantai nilai jagung menggunakan metode wawancara mendalam (in - depth interview) dengan key-person A-B-G-C yang berkompeten terhadap pengembangan usahatani jagung dengan penentuan key - person menggunakan metode purposive sampling.

Kata Kunci: Tanaman Pangan; Jagung; Analisis Rantai Nilai (VCA) 


\section{PENDAHULUAN}

Indonesia adalah salah satu negara yang dianugrahi dengan berbagai macam kelebihan, dengan luas wilayah menurut data statistik Indonesia tahun 2012 mencapai $1.910 .931,32 \mathrm{~km}^{2}$. Secara geografis Indonesia berbatasan dengan beberapa negara dan samudra, batas utara dengan Malaysia, Filipina, Singapura dan Laut Cina Selatan, batas selatan dengan Australia dan Samudra Hindia, batas barat dengan Samudra Hindia, batas timur dengan Papua Nuigini, Timor Leste dan Samudra Pasifik. Indonesia dianugrahi berbagai kelebihan.Kelebihan yang dimiliki Indonesia salah satunya adalah kekayaan alam yang berlimpah, baik di lautan dan daratan. Selain kekayaan alam Indonesia memiliki sumber daya manusia yang banyak. Kekayaan tersebut apabila dikelola secara baik dan benar secara ekonomi Indonesia merupakan pasar yang potensial untuk dikembangkan guna meningkatkan dari pendapatan negara.Salah satu kekayaan alam Indonesia adalah dalam hasil pertanian. Sektor pertanian memiliki peranan penting dalam perekonomian Indonesia dan menjadi prioritas pembangunan nasional, peranan tersebut dijelaskan oleh Rejeki (2006) antara lain: Katalisator pembangunan, Stabilisator harga dalam perekonomian, Sumber devisa non migas.

Data Grobogan dalam angka (2013) menjelaskan sektor pertanian menjadi sektoryang menyumbang terbesar dan dari tahun 2009 sampai 2013 mengalami peningkatan terus menerus baru kemudian diikuti sektor perdagangan dan jasa. Sektor pertanian yang menjadi penyumbang terbesar di Kabupaten Grobogan menjadikan Kabupaten Grobogan menjadi salah satu Kabupaten di Jawa Tengah yang sektor unggul dalam hal pertanian.

Sektor pertanian menjadi penyumbang terbesar karena keberadan lahan pertanian masih sangat luas, selain itu masyarakatnya sebagian besar sebagai petani, berdasarkan hal tersebut sektor pertanian di Kabupaten Grobogan menjadi unggulan. Grobogan dalam Angka (2014) menjelaskan salah satu subsektor yang menyumbang terbesar dalam sektor pertanian di Kabupaten Grobogan adalah tanaman pangan. Hasil pertanian di Kabupaten Grobogan yang didominasi oleh tanaman pangan karena memang keberadaan lahan pertanian yang berupa sawah, tegalan masih sangat luas dan tersebuar hamper diseluruh wilayah Kabupaten Grobogan. Salah satu hasil pertanian tanaman yang menjadi unggulan selain padi adalah jagung.

Jagung menjadi tanaman yang diunggulkan karena bisa menjadi pengganti padi atau ditanam setelah masa tanam padi. Berdasar jenis lahan yang ada di Kabupaten Grobogan yang terdiri dari lahan teknis, lahan tadah hujan dan lahan hutan tanaman menjadikan jagung bisa tumbuh dengan baik. Lahan teknis dalam 1 tahun memiliki 3 kali masa tanam yaitu jagung 2 kali kemudian bari jagung berikutnya lahan tadah hujan yang memiliki masa tanam 3 kali yaitu padi 1 kali jagung 2 kali dan yang terakhir lahan hujan yang sepanjang tahun ditanami jagung. Berdasarkan kelebihan tersebut jagung menjadi tanaman pangan icon di Kabupaten Grobogan sehingga perlu untuk lebih dikembangkan lagi potensi pertanian jagung.

Jagung yang menjadi tanaman pangan dengan hasil panen terbesar kedua setelah padi di Kabupaten Grobogan dapat dilihat dari luas panen pada Grobogan dalam Angka (2012), yang dari tahun 2007 sampai 2011 menunjukan kondisi yang cukup bagus akan tetapi pada tahun 2001 mengalami penurunan yang sangat signifikan sehingga berdampak pada prodksi jagung atau panen jagung, akan tetapi walaupun terjadi penurunan lahan panen dan produksi tidak serta merta memberikan kerugian karena dari sisi produktivitasnya mengalami peningkatan sehingga bisa dikatakan pada kondisi ideal.

Data Dinas Pertanian Kabupaten Grobogan (2012) ada beberapa kecamatan di Kabupaten Grobogan yang menjadi penghasil jagung, salah satu yang menyumbang besar adalah Kecamatan Toroh. Kecamatan Toroh walaupun tidak menjadi penghasil jagung utama akan tetapi toroh secara letak daerah sangat cocok untuk ditanami jagung karena memiliki ketiga karakter lahan baik lahan teknis, tadah hujan maupun hutan. Kecamatan Toroh juga 
menjadi kecamatan percontohan untuk hasil jagung konsumsi manusia karena berdasarkan hasil wawancara dengan Kepala Bidang Tanaman Pangan Dinas Pertanian Kabupaten Grobogan hasil panen jagung diperuntukan pakan ternak sehingga perlu untuk lebih dikembangkan lagi.

Permasalahan pertanian jagung meliputi baik dari sisi produksi maupun dalam hal pemasaran. Penurunan jumlah lahan panen dan produksi yang terjadi pada tahun 2011 tidak hanya karena alih fungsi lahan tetapi juga karena harga jagung diterima petani cenderung rendah membuat petani beralih ke tembakau dan palawija. Kondisi jagung yang surplus membuat harga jagung semakin lemah keberadaan lembaga yang menunjang baik Dinas Pertanian maupun Gapoktan kurang begitu membantu karena petani saat panen langsung menjual kepada tengkulak sehingga petani hanya berperan sebagai price taker. Kurangnya informasi juga memicu harga yang lemahpetani di Kecamatan Toroh kurang mengetahui informasi mengenai harga jagung dan lemah dalm hal teknik perawatan jagung dari panen hingga siap jual, untuk mendapatkan harga jagung yang sesuai dengan kualitas yang bagus dibutuhkan setidaknya 110 hari kemudian dilakukan penjemuran hingga mencapai kadar air tertentu baru berikutnya dilakukan penyimpanan akan tetapi petani di Kecamatan Toroh tidak mempunyai lahan untuk menjemur dan tidak memiliki fasilitas penyimpanan yang bagus karena untuk penyimpanan jagung harus dengan cara yang benar yaitu dengan memberi ruang khusus pada dasar tempat penyimpanan jagung untuk pembakaran yang kemudian asap hasil pembakaran tersebut akan mengasapi jagung yang ada di atas tempat pembakaran tersebut sehingga akan membuat hama jagung tidak menyerang. Berdasarkan kondisi ini lah petani jagung kurang mendapatkan keuntungan yang proporsional sehingga perlu adanya perbaikan untuk lebih meningkatkan kesejahteraan petani jagung.

Permasalahan jagung tidak hanya yang dialami petani, untuk peningkatan hasil jagung yang surplus sudah dilakukan pengolahan yang dibantu oleh Dinas BKP (Badan Ketahanan Pangam) Kabupaten Grobogan. Kendala yang dialami para pengolah yaitu dalam hal pemasaran karena berdasarkan hasil wawancara pemasaran jagung dilakukan sebatas mulut ke mulut sehingga kurang efektif.

Analisis rantai nilai bisa membantu untuk mengetahui pelaku yang ada dalam rantai pemasaran yang kemudian bisa dirumuskan strategi yang tepat baik dengan memotong rantai ataupun dengan memberikan solusi bagi tiap pelaku.Sukayana (2013) menyatakan dalam suatu kegiatan pertanian perlu diperhatikan dalam hal sistem produksi mulai dari tanam sampai dengan perawatan kemudian setelah itu dalam hal sistem panen kemudian dalam serangkaian kegiatan rantai nilai pemasaran menjadi kegiatan yang penting untuk melihat seberapa efektifkah rantai yang tercipta baru setelah itu akan terlihat margin harga antar pelaku dalam rantai nilai.Irianto (2013) menemukan dalam rangkaian kegiatan rantai nilai tiap pelaku yang berperan di dalamnya akan mendapatkan keuntungan yang proporsional akan tetapi petani kurang mendapatkan hasil yang proporsional karena petani kurang mendapatkan informasi baik dari harga, sistem pemasaran, maupun dalam hal kualitas tanaman yang dihasilkan, apabila sudah tercipta suatu rangkaian kegiatan yang baik akan membentuk rantai yang efisien.

Tujuan yang ingin dicapai dalam penelitian ini adalah: (1) Manganalisis Rantai Nilai jagung di Kecamatan Toroh Kabupaten Grobogan. (2) Merumuskan strategi untuk mengembangkan Jagung sebagai upaya ketahahanan pangan di Kabupaten Grobogan.

\section{TINJAUAN PUSTAKA \\ Rantai Nilai}

Rantai nilai adalah suatu metode penilaian dimana bisnis dilihat sebagai rantai aktivitas yang mengubah input menjadi output yang bernilai bagi pelanggan. Nilai bagi pelanggan berasal dari tiga sumber dasar: aktivitas yang membedakan produk, aktivitas yang 
menurunkan biaya produk, dan aktivitas yang dapat segera memenuhi kebutuhan pelanggan (Pearce dan Robinson 2008).Porter (1985) menjelaskan analisis rantai nilai dapat digunakan sebagai alat analisis strategi yang digunakan untuk memahami secara lebih baik terhadap keunggulan kompetitif, dimana perusahaan dapat meningkatkan nilai tambah maupun penurunan biaya sehingga membuat usaha lebih kompetitif.

Rantai nilai merupakan semua aktivitas yang dilakukan sampai pada distribusinya pada konsumen akhir (Campbell 2008 dalam Sukayana 2013).Kaplinsky dan Morris (2000) dalam Dzanjal (2013) mendefinisikan rantai nilai sebagai berbagai kegiatan yang diperlukan untuk membawa produk atau layanan dari konsepsi, melalui fase yang berbeda dari produksi, pengiriman ke konsumen akhir dan pembuangan akhir setelah digunakan.Ahmed (2007) dalam Dzanjal (2013) menyebutnya sebagai struktur fisik, ekonomi dan sosial transaksi antara individu dan organisasi yang terlibat dalam transformasi bahan baku menjadi produk akhir.Porter(1985) menjelaskan rangkaian kegiatan dalam rantai nilai dari produsen ke konsumen dibagi menjadi beberapa aktivitas digolongkan menjadi dua: (1) Aktivitas utama:Inbound logistics: persediaan bahan baku untuk proses produksi, Operation: proses pengolahan bahan baku menjadi produk yang siap digunakan, Outbound logistics: pengiriman barang / produk ke sepanjang alur suplai menuju konsumen akhir, Marketing and sales:meliputi kegiatan promosi maupun pelayanan produk, purna jual, penanganan keluhan dan lain sebagainya; (2) Aktivitas pendukung:Procurement: mencakup kegiatan penanganan pembelian barang, Technology development: pemanfaatan teknologi untuk penghematan biaya dan meningkatkan keuntungan, Human resource management: penanganan rekruitmen dan seleksi pelatihan dan pengembangan SDM, Firm infrastructure: pengelolaan sistem informasi, perencanaan, maupun pengawasan.

Kaplinsky and Morris (2001) dalam Irianto (2013) berpendapat dalam rangkaian analisis rantai nilai ada tujuh tahapan: (1) Identifikasi pelaku (entry point), penelusuran pelaku; (2) Value chain mapping, pembuatan bagan pelaku utama dirunut baik kedepan maupun ke belakang; (3) Penentuan segmen produk dan faktor kunci penentu keberhasilan pasar tujuan yang mencakup identifikasi pihak yang dapat dilibatkan dalam perbaikan rantai nilai (analysis of governance structure); (4) Analisis metode produsen untuk mengakses pasar untuk menentukan kunci sukses (critical success factors). Perkembangan sistem produksi saat ini cenderung bergeser dari pola tarikan pemasok (supplier push) ke arah dorongan pasar (market pulled), yang berarti orientasi keberhasilan suatu produk bukan ditentukan oleh kekuatan perusahaan untuk memasok sejumlah produk namun ditentukan oleh kemampuan perusahaan (jaringan, teknologi, produksi, dll) untuk memenuhi kebutuhan pasar baik dalam kuantitas maupun kualitas yang sesuai. Maka perlu memperhatikan karakteristik pasar produk akhir di setiap rantai yang terdapat beberapa komponen: (a) Pasar terbagi dalam beberapa segmen, setiap pasar memiliki karakteristik yang beda dan kemudian akan menciptakan segmen pasar kemudian akan memunculkan ukuran dan pertumbuhan pasar. (b) Karakter pasar; (5) Melakukan bencmarking dengan competitor atau bisnis yang sejenisMembandingkan kinerja bisnis rantai nilai obyek dengan obyek sejenis yang mempunyai kinerja lebih baik/ sebagai alat acuan analisis efisisensi produksi pihak - pihak yang terlibat dalam value chain; (6) Mengkoordinasikan rantai nilai dengan jejaring yang terkait; (7) Perbaikan rantai nilai (Upgrading Value Chain): (a) Perbaikan dalam proses dapat terjadi dalam perusahaan maupun antar pelaku karena prose interaksi; (b) Perbaikan produk baik dalam perusahaan maupun antar pelaku; (c) perubahan posisi melalui penyesuaian aktivitas dalam hubungan (link) antar pelaku atau menggeser hubungan untuk mengkaitkan antar pelaku lain; (d) Penarikan suatu rantai nilai kemudian mengkaitkan dengan rantai nilai baru. 
Eka Widayat Julianto Dan Darwanto: Analisis Rantai Nilai (Value Chain) Jagung Di Kecamatan Toroh Kabupaten Grobogan

\section{Margin Pemasaran}

Marjin pemasaran merupakan selisih harga dari dua tingkat rantai pemasaran (Daly dan Fane dalam Sukayana 2013).Pearce dan Robinson (2008) mendefinisikan margin pemasaran sebagai selisih harga dari dua atau lebih dari tingkat rantai pemasaran, atau ditingkat produsen dan eceran ditingat konsumen.

Zein dalam Monzery (2013) menjelaskan untuk menghitung margin dari setiap lembaga pemasaran, digunakan rumus:

$$
\mathrm{M}_{\mathrm{p}}=\mathrm{P}_{\mathrm{r}}-\mathrm{P}_{\mathrm{f}}
$$

Keterangan

$\mathrm{M}_{\mathrm{p}}=$ Margin Pemasaran $(\mathrm{Rp} / \mathrm{kg})$

$\mathrm{P}_{\mathrm{r}}=$ Harga ditngkat konsumen $(\mathrm{Rp} / \mathrm{kg})$

$\mathrm{P}_{\mathrm{f}}=$ Harga ditingkat produsen $(\mathrm{Rp} / \mathrm{kg})$

Menghitung besarnya nilai tambah yang diterima setiap pelaku dilakukan dengan menghitung marjin keuntungan menurut Zein dalam Monzery (2014), digunakan rumus:

$$
\mathrm{D}_{\mathrm{ij}}=\mathrm{H}_{\mathrm{jj}}-\mathrm{H}_{\mathrm{bj}}-\mathrm{C}_{\mathrm{ij}}
$$

Keterangan:

$\mathrm{D}_{\mathrm{ij}} \quad=$ keuntungan lembaga pemasaran $\mathrm{ke}-\mathrm{j}$

$\mathrm{H}_{\mathrm{jj}} \quad$ = harga jual lembaga pemasaran

$\mathrm{H}_{\mathrm{bj}} \quad$ = harga jual lembaga pemasaran $\mathrm{ke}-\mathrm{j}$

$\mathrm{C}_{\mathrm{ij}} \quad$ = biaya melakukan fungsi pemasaran ke $-\mathrm{I}$ oleh lembaga pemasaran ke- $\mathrm{J}$

\section{Kelembagaan}

Wariso (1998) dalam Wahyuni (2003) membagi kelembagaan ke dalam dua pengertian, yaitu institut yang menunjuk pada kelembagaan formal misalnya: organiasasi, badan dan yayasan mulai dari tingkat keluarga, rukun keluarga, desa sampai pusat, sedangkan institusi merupakan suatu kumpulan norma - norma atau nilai - nilai yang mengatur perilaku manusia untuk memenuhi kebutuhannya. Kelembagaan petani yang dimaksud adalah kelembagaan formal (organisasi) atau institusi (norma - norma) yang berkaitan dengan petani. Kelembagaan petani (perkebunan, peternakan, nelayan, pembudidaya ikan, pengolah ikan dan masyarakat di dalam dan di sekitar kawasan hutan) adalah lembaga yang ditumbuh kembangkan diri oleh dan untuk pelaku utama.Pelaku utama yang dimaksud adalah masyarakat di dalam dan di sekitar hutan, petani, pekebun, peternak, nelayan, pembudi daya ikan, pengolah ikan beserta keluarga intinya (UU No. 16 Tahun 2006).

Peran kelembagaan petani yang mendukung keberlanjutan pertanian diberikan kriteria (Nurmala dkk, 2012): (1) Subsistem sarana: perencanaan, pengolahan, pengadaan sarana produksi yang memungkinkan penerapan suatu teknologi usahatani dan pemanfaatan SDA secara optimal; (2) Subsistem Usahatani: pembinaan dan pengembangan usahatani dalam rangka peningkatan produksi pertanian, baik usahatani pertanian rakyat maupun usahatani besar; (3) Subsistem Pengolahan: pengolahan hasil secara sederhana di tingkat petani dan penanganan pasca panen komoditi pertanian yang dihasilkan sampai pada tingkat pengolahan lanjut selam bentuk, susunan dan citarasa komoditi tersebut tidak berubah; (4) Subsistem Pemasaran: pemasaran hasil usahatani yang masih segar atau hasil olahannya mencakup kegiatan distribusi dan pemasaran di dalam negeri dan ekspor; (5) Subsistem pelayanan atau pendukung (Departemen Pertanian 2011 dan Zakaria 2003) jasa perbankan, jasa angkutan, asuransi, penyimpanan dan lain - lain.

Sesuai dengan fungsi beberapa lembaga petani sebagai kelas belajar dan unit produksi/ usaha (Pemertan nomor 273/kpts/OT.160/4/2007) dapat disimpulkan terdapat dua jenis peran lembaga yang penting dalam sistem agribisnis yaitu sebagai penyedia informasi dan sebagai penyedia fisik/jasa pada masing - masing subsistem.Rheza dan Karlinda (2013), padaaspek 
kelembagaan dalam rantai nilai pemasaran yang tidak berjalan dengan baik pada akhirnya semakin memperlemah posisi tawar petani.

\section{Pemasaran}

Pemasaran adalah fungsi bisnis yang mengidentifikasi keinginan dan kebutuhan yang belum terpenuhi sekarang dan mengukur seberapa besar pasar akan dilayani, menentukan pasar sasaran mana yang paling baik dilayani oleh organisasi dan menentukan berbagai produk, jasa, dan program yang tepat untuk melayani pasar tersebut. Pemasaran merupakan proses sosial dan manajerial yang mana seseorang atau kelompok memperoleh yang mereka butuhkan dan inginkan dengan cara pertukaran produk dan nilai. Pemasaran bisa berarti seseorang yang mencari sumber daya orang lain dan bersedia manawarkan sesuatu yang bernilai sebagai imbalannya. Kotler (1993) menjelaskan dalam rantai pemasaran memiliki beberapa konsep:

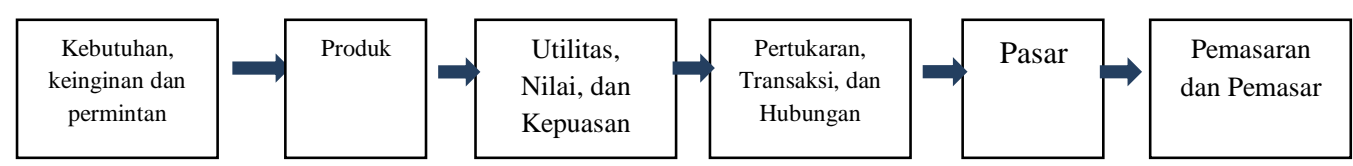

Gambar 1. Konsep Rantai Pemasaran

Sumber: Kotler, 1993

\section{METODE PENELITIAN}

Penelitian Rantai Nilai jagung yang dilakukan di Kabupaten Grobogan mengambil Kecamatan Toroh dengan enam desa untuk dijadikan sampel antara lain: Desa Depok, Desa Krangganharjo, Desa Tambirejo, Desa Plosoharjo, Desa Tunggak dan Desa Boloh.Pemilihan lokasi tersebut berdasarkan letak desa yang menjadi sampel mencakup semua jenis lahan yang ada di Kabupaten Grobogan.

Data yang digunakan dalam penelitian ini menggunakan dua jenis data yaitu data primer dan data sekunder. Sumber data primer diperoleh dari wawancara pada para Petani jagung di Kecamatan Toroh, Tengkulak, Pedagang Pengepul, Pedagang Kecil dan Pedagang Besar serta key-person dari unsur ABGC (Academy, Government, Business, Community).Data sekunder sendiri diperoleh dari beberapa lembaga atau instansi terkait seperti BPS Provinsi Jawa Tengah, BPS Kabupaten Grobogan, Dinas Pertanian Kabupaten Grobogan, DISPERINDAG Kabupaten Grobogan, Badan Ketahanan Pangan Kabupaten Grobogan dan Balai Penelitian Pertanian Kecamatan Toroh. Selain dari beberapa instansi tersebut data sekunder juga diperoleh dari buku serta jurnal publikasi sesuai yang terkait.

Banyaknya responden pada penelitian ini sejumlah 100 yang ditentukan dengan menggunakan pendekatan purpusive samplingdengan tujuan untuk memperoleh sampel yang representatif berdasarkan kriteria yang ditentukan selain itu juga pemilihan berdasarkan kriteria seseorang yang memiliki kekayaan informasi dan merupakan petani jagung.Penentuan jumlah sampel 100 karena dari jumlah tersebut sudah bisa mewakili dari populasi yang ada dan karena karakteristik petani yang cenderung homogen.

Selain untuk penentuan responden (petani) dalam penelitian ini juga ditentukan aktor yang menjadi pelaku dalam kegiatan rantai nilai.Sampel informan channel dalam penelitian rantai nilai komoditas jagung selain petani jagung yang dijadikan sampel penelitian, terdapat aktor lain yang dijadikan sampel yaitu tengkulak/pedagang kecamatan, pedagang kecil, pengepul besar, dan pengolah jagung, namun karena populasi dari ketiga aktor tersebut menyebar dan tidak dapat diketahui, maka teknik pegambilan sampel pada masing-masing aktor tersebut dengan menggunakan metode Snowball Sampling. 
Eka Widayat Julianto Dan Darwanto: Analisis Rantai Nilai (Value Chain) Jagung Di Kecamatan Toroh Kabupaten Grobogan

Aktor yang berperan dalam rantai nilai tidak hanya dalam rantai akan tetapi juga aktor yang berperan dalam pembuatan strategi perbaikan. Penentuan responden kunci (key-person) yang berkompeten terhadap pengembangan usaha tani jagung diperoleh berdasarkan pendekatan A-B-G-C (Akademisi, Bussines, Government, Community).

Tabel 1. Daftar Keyperson

\begin{tabular}{cllc}
\hline Bidang & \multicolumn{1}{c}{ Instansi } & \multicolumn{1}{c}{ Lokasi } & Jumlah \\
\hline Akademisi & Dosen Universitas Diponegoro & Semarang & 1 \\
& Dosen Universitas Wahid Hasyim & Semarang & 1 \\
Pebisnis & Pedagang Jagung & Kecamatan Toroh & 1 \\
Pemerintah & Kasi Tanaman Pangan Dinas & Kabupaten & 1 \\
& Pertanian & Grobogan & \\
& PPL & Kecamatan Toroh & 1 \\
Komunitas & Ketua Kelompok Tani & Kecamatan Toroh & 1 \\
\hline
\end{tabular}

\section{HASIL DAN PEMBAHASAN}

\section{Peta Rantai Nilai (Value Chain) Jagung}

Pemetaan rantai nilai jagung merupakan gambaran dari proses distribusi jagung mulai dari produsen yaitu petani jagung sampai dengan konsumen. Pemetaan rantai nilai usaha tani jagung terdiri dari tiga bagian yaitu fungsi utamarantai nilai usahatani jagung dan pelaku utama rantai nilai usahatani jagung serta lembaga yang terkait yang menunjang keberlangsungan rantai nilai usahatani jagung. Fungsi utama rantai nilai meliputi proses distribusi, pengumulan atau perantara serta pendistribusian. Pelaku utama dari rantai nilai usahatani jagung yaitu petani jagung, tengkulak, pengepul besar, pedagang kecil dan pengolah.Lembaga penunjang yaitu dengan adanya kelompok tani yang membantu dalam pelaksanaan usahatani jagung. Pada rantai nilai jagung diketahui terdapat beberapa pelaku yang berperan dalam alur rantai dan dibedakan menjadi dua macam yaitu jagung segar dan jagung olahan.

Pelaku yang berperan dalam rantai nilai jagung segar antara lain: petani, tengkulak/pedagang kecamatan, pengepul besar, pedagang kecil dan konsumen. Alur rantai nilai jagung segar dibagi menjadi beberapa alur (1) Petani - Tengkulak/ Pedagang Kecamatan - Pengepul Besar - Konsumen Antara;(2) Petani - Tengkulak/ Pedagang Kecamatan Pedagang Kecil - Konsumen.Pelaku rantai nilai jagung olahan yang berperan antara lain: petani, pedagang kecil, pengolah dan konsumen. Alur rantai nilai jagung olahan dibagi menjadi beberapa alur: (1) Petani - Pedagang kecil - Pengolah - Konsumen; (2) Petani Pengolah - Konsumen.

\section{Analisis Rantai Nilai (Value Chain) Jagung}

Rantai nilai jagung dapat dilihat pelaku mana yang mendapatkan keuntungan paling banyak yang dilihat dari marjin tiap pelaku dengan laba yang diperoleh untuk per $\mathrm{kg}$ yang dijual dalam rantai nilai jagung segar maupun jagung olahan.

Harga jual jagung biasa dari tingkat petani jagung hingga ke pedagang besar, harga jagung di tingkat petani Rp 2.250/kg sedangkan harga ditingkat pengepul atau tengkulak naik menjadi Rp. 2.800/kg.Margin antara petani dengan tengkulak yaitu sebesar Rp 550/kg, margin antara tengkulak dengan pengepul sebesar Rp 200/kg. Pihak yang memperoleh profit tertinggi per $1 \mathrm{~kg}$ yaitu tengkulak dengan profit $\mathrm{Rp} \mathrm{400,} \mathrm{dan} \mathrm{petani} \mathrm{memperoleh} \mathrm{profit} \mathrm{per} 1$ $\mathrm{kg}$ sebesar Rp 235 sedangkan pengepul memperoleh profit per $1 \mathrm{~kg}$ sebesar Rp 50. Analisis 
rantai nilai jagung biasa pihak yang diuntungkan yaitu tengkulak karena memperoleh margin pemasaran lebih banyak diantara petani dan tengkulak.

Harga jual jagung biasa dari tingkat petani jagung hingga ke pedagang besar, harga jagung di tingkat petani Rp 2.250/kg sedangkan harga ditingkat pengepul atau tengkulak naik menjadi Rp. 2.800/kg. Margin antara petani dengan tengkulak yaitu sebesar Rp 550/kg,

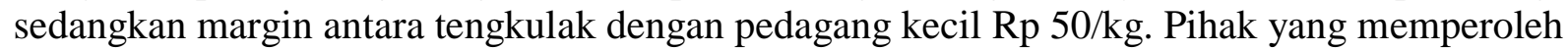
profit tertinggi per $1 \mathrm{~kg}$ yaitu tengkulak dengan profit $\mathrm{Rp} 400$, dan petani memperoleh profit per $1 \mathrm{~kg}$ sebesar Rp 235 sedangkan pedagang kecil memperoleh profit per $1 \mathrm{~kg}$ sebesar Rp 150.Analisis rantai nilai jagung biasa pihak yang diuntungkan yaitu tengkulak karena memperoleh margin pemasaran dan keuntungan lebih banyak diantara petani dan pengepul besar.

Analisis rantai nilai jagung olahan menjelaskan terdapat beberapa pelaku yang berperan yaitu petani jagung, pedagang kecil dan pengolah. Berdasarkan harga jual jagung dari tingkat petani hingga pengolah, harga jagung ditingkat petani Rp 2.250/kg, harga jagung ditingkat pedagang kecil dijual dengan harga $\mathrm{Rp} 2.700 / \mathrm{kg}$ dan harga jagung olahan ditingkat pengolah sebesar Rp 15.000/kg. Margin pemasaran diantara petani jagung dengan pedagang kecil sebesar Rp 550 sedangkan margin antara tengkulak dengan pedagang besar Rp 12.300.

Biaya dan hasil yang diperoleh setiap pelaku dari hasil tersebut menggambarkan setiap pelaku mulai dari petani, tengkulak atau pedagang kecamatan, pedagang kecil, pengolah sudah mendapatkan keuntungan sehingga alur rantai nilai jagung segar maupu olahan masih efisien,akan tetapi rantai nilai tidak hanya menjelaskan bentuk rantai akan tetapi juga bagaimana bisa memperbaiki atau memberikan kebijakan dan solusi dalam hal ini pelaku yang perlu mendapatkan perhatian adalah petani karena belum mendapatkan keuntungan yang proporsional sesuai jerih payah yang dilakukan dari masa tanam hingga panen, banyak faktor yang menyebabkan hal itu terjadi bisa karena hama, cuaca, pola fikir petani, keterbatasan informasi pasar, dll. Harga jual jagung yang diterima petani dirasa kurang oleh karena itu perlu dilakukan upaya untuk lebih mendongkrak harga yang diterima petani tersebut.

Jagung yang merupakan salah satu tanaman pertanian yang tumbuh subur di Kabupaten Grobogan menjadikan hasil panen melimpah sehingga pertanian jagung di Kabupaten Gobogan selalu mengalami surplus setiap tahunnya, dengan adanya kondisi seperti ini maka bisa dimanfaatkan untuk menambah penerimaan.

Tabel 2. Konsumsi Jagung di Kabupaten Grobogan Tahun 2009 - 2013

\begin{tabular}{cccc}
\hline Tahun & Produksi & Kebutuhan & Surplus \\
\hline 2009 & 699.223 & 559.379 & 23.193 \\
2010 & 708.013 & 566.410 & 23.334 \\
2011 & 502.214 & 401.771 & 23.498 \\
2012 & 530.884 & 424.707 & 23.659 \\
2013 & 559.555 & 447.644 & 23.821 \\
\hline
\end{tabular}

Tabel 2 menjelaskan konsumsi jagung di Kabupaten Grobogan dari tahun 2009 - 2013 lebih kecil daripada produksinya sehingga selalu mengalami surplus. Pemenuhan kebutuhan jagung di Kabupaten Grobogan tidak perlu melakukan impor dari daerah lain justru bisa melakukan ekspor. Pada hasil analisis value chain jagung justru menunjukkan bahwa jagung yang dihasilkan di daerah Grobogan lari ke daerah lain yang peruntukannya sebagai pakan ternak sedangkan untuk Kabupaten Grobogan sendiri masih belum dimanfaatkan secara optimal. 
Hasil wawancara dengan Kasi Tanaman Pangan Dinas Pertanian Kabupaten Grobogan, Kecamatan Toroh khususnya Desa Tunggak menjadi salah satu kecamatan percontohan penghasil jagung yang berkualitas untuk konsumsi manusia, sehingga sangat disayangkan apabila jagung yang lari keluar daerah hanya sebagai pakan ternak saja, dengan adanya rencana itulah mulai diberikan berbagai macam usaha untuk mencapai tujuan tersebut. Salah satu usaha yang dilakukan adalah mulai ditanam jagung yang organik, untuk keberadaan jagung yang berlimpah pemerintah memberikan pelatihan untuk membuat berbagai macam olahan jagung. Berdasar analisis value chain jagung ada pelaku pengusaha/pengolah walaupun skalanya masih home industry untuk daerah Kecamatan Toroh sudah terdapat pengolah yang terdapat di Desa Boloh hasil olahannya beras jagung, hal ini menunjukan sudah ada usaha nyata untuk mengembangkan jagung, dengan begitu petani bisa memanfaatkan ini untuk memberikan tambahan.

\section{Peran Kelembagaan}

Peran lembaga pertanian dalam sistem agribisnis bisa berupa penyedia informasi maupun sebagai penyedia fisik/ jasa (Permetan nomor 273/Kpts/OT.160/4/2007).Wariso (1998) dalam Wahyuni (2003) mendefinisikan kelembagaan kedalam dua pengertian, yaitu sebagai institut yang menunjuk pada kelembagaan formal misalnya: organisasi, badan dan yayasan mulai dari tingkat keluarga, rukun keluarga, desa sampai pusat, sedangkan institusi merupakan suatu kumpulan norma - norma atau nilai - nilai yang mengatur perilaku manusia untuk memenuhi kebutuhannya.

Manfaat dari keberadaan lembaga antara lain:

1. Norma: menjadi pengikat/ aturan secara tidak tertulis kepada petani dalam proses bertani dari tanam sampai panen hingga penanganan apabila ada kendala.

2. Badan Lembaga: (1) Akademisi: bisa menjadi media untuk belajar petani guna mendapatkan ilmu yang baru dalam bertani, karena keberadaan akademisi harus berperan aktif dalam pengembangan pertanian (pelatihan dan penyuluhan) baik dari sisi tata cara penanaman hingga penemuan inovasi baru yang berdampak pada peningkatan hasil panen; (2) Pemerintah atau Dinas terkait: manfaat dari keberadaan dinas bisa menjadi media jembatan petani dengan dunia luar dalam hal ini terkait pemasaran, selain itu keberadaan pemerintah yang diwakili dinas bisa menjadi media penyedia saprodi yang membantu dalam pemenuhan kebutuhan petani dalam proses tanam hingga panen, dinas juga dituntut untuk berperan aktif dalam pembinaan guna meningkatkan kapasitas SDM dan selalu melakukan pendampingan, dinas terkait juga bisa memberikan bantuan atau memfasilitasi untuk pendirian kelompok tani yang sangat banyak manfaatnya; (3) Kelompok tani: manfaat dari keberadaan kelompok tani bisa sebagai media bertukar informasi selain itu juga sebagai tempat untuk mengumpulkan hasil panen sehingga bisa mencapai kuota tertentu yang mencukupi untuk langsung disalurkan kepada perusahaan sehingga harga bisa lebih tinggi.

Dalam setiap rangkaian kegiatan pertanian keberadaan kelompok tani atau gapoktan menjadi sangat penting karena bisa menjadi wadah bagi petani dengan begitu bisa memperbaiki kualitas pertanian. Keberadaan kelompok tani tidak akan seimbang tanpa dukungan dari lembaga pemerintah yang diwakili oleh PPL yang bisa menjadi jembatan aspirasi petani kepada pemerintah daerah selain itu juga bisa membantu dalam sarana pembelajaran. Keberadaan kelompok tani bisa sangat efektif apabila kelompok tani aktif mengadakan pertemuan rutin untuk membahas kendala maupun cara mengatasi kendala tersebut, jadi tidak menjadi jaminan walaupun suatu kelompok tani tersetruktur dengan baik bisa memberikan manfaat bagi anggota kelompok tani tersebut. Selain kelompok tani peran PPL sebagai wakil dari Dinas Pertanian bisa sangat efektif apabila bisa mengayomi dari kelompok tani, di Kecamatan Toron keberadaan dari PPL masih belum dapat dirasakan 
kelompok tani karena jumlah PPL yang kurang memadai cakupan untuk setiap satu orang PPL terlalu luas sehingga penanganan kurang merata, selain itu walaupun d Kecamatan Toroh keberadaan kelompok tani sangat banyak untuk masing - masing desa akan tetapi kelompok tani tersebut tidak berperan aktif sehingga anggotanya pun bergerak masing - masing. Suatu lembaga pertanian (kelompok tani) bisa dikatakan efektif karena beberapa hal sebagai berikut: (1) Semakin usia lembaga bertambah maka perannya terhadap pemberian informasi terkait alat mesin pertanian semakin baik; (2) Semakin petani mudah menerima perubahan salah satu faktornya adalah dari sisi tingkat pendidikan maka semakin mudah petani menerima informasi yang disediakan oleh lembaga terkait yang bersangkutan; (3) Semakin bagusnya koordinasi dalam lembaga maka akan membuat pemberian informasi akan mudah diterima.

Lembaga yang berperan dalam rantai nilai jagung di Kecamatan Toroh tidak hanya sebatas pada kelompok tani untuk setiap desa yang menjadi lokasi penelitian sudah tersedia PPL (Petugas Penyuluh Lapangan) yang mewakili dari Dinas Pertanian Kabupaten Grobogan.

Hasil wawancara dengan lembaga pertanian Kecamatan Toroh kelompok tani, GAPOKTAN, PPL memiliki tugas dan fungsinya masing - masing. Untuk tugas dan fungsi dari kelompok tani berdasarkan hasil wawancara kelompok tani yang diwakili ketua kelompok menjadi media untuk pembelian benih dan pupuk karena kelompok tani sering mendapatkan promosi produk baru dari penghasil pupuk maupun benih jagung sehingga kelompok tani bisa memberikan harga yang lebih murah daripada membeli di luar selain itu kelompok tani menjadi media bertukar informasikarena rutin melakukan pertemuan untuk melakukan pembahasan atau diskusi mengenai kesulitan yang dialami baik dalam hal hama, perawatan, dll akan tetapi kelompok tani di desa penelitian belum bisa untuk berperan dalam pengumpulan hasil panen karena memang keterbatasan tempat dan dana sehingga petani yang tergabung dalam kelompok tani tetap saja saat panen langsung menjual ke tengkulak yang membuat harga yang diterima rendah.

Hasil olah data yang tersedia dari wawancara untuk peran dari kelompok tani tidak akan maksimal apabila tidak mendapatkan bantuan dari dinas yang diwakili PPL. Kehadiran dari PPL yang ada di desa penelitian sebenarnya sudah berperan aktif dalam membantu mengembangkan produktivitas jagung PPL aktif memberikan penyuluhan akan tetapi peran tersebut masih belum terlalu maksimal karena jumlah PPL yang masih terbatas yang berdampak 1 PPL bisa mengampu beberapa desa sehingga ada desa atau kelompok tani yang tidak mendapatkan penyuluhan sehingga petani merasa tidak adil, akan tetapi informasi yang diberikan PPL sudah terbilang lengkap sehubungan dengan proses penanaman jagung (tanam sampai panen)untuk menunjang informasi yang diberikan dalam hal ini PPL ikut membantu sehingga petani mendapatkan informasi yang lebih akurat sehingga bisa membantu peningkatan hasil sebagai buktinya sudah tercipta koordinasi yang bagus walaupun ada penurunan lahan tanam yang berdampak pada jumlah produksi (panen) akan tetapi untuk produktivitasnya tetap mengalami kenaikan.

Hasil wawancara dengan pelaku rantai nilai jagung, peran lembaga pertanian dalam rantai nilai jagung di Kecamatan Toroh tidak hanya dalam proses produksi jagung sampai panen tetapi juga untuk pengolahan jagung.Pemerintah juga sudah melakukan pendampingan dan pelatihan yang diwakili BKP Kabupaten Grobogan membantu masyarakat untuk lebih kreatif dengan membuat hasil olahan jagung sudah ada beberapa home industry salah satu diantaranya di Desa Boloh salah satu hasil olahannya adalah beras jagung yaitu hasil dari jagung dibuat pupuk yang kemudian dipadatkan dengan alat khusus sehingga menjadi bulir beras siap konsumsi dengan adanya pendampingan tersebutlah membuat jagung memiliki nilai tambah yang berdampak pada perbaikan ekonomi masyarakat Kecamatan Toroh dan Kabupaten Grobogan. Pelaku industri rumahan pengolah jagung dalam proses pemasaran hasil jagung olahan masih terbilang sulit dan berdasarkan hasil wawancara beras jagung di 
pasarkan hanya lewat mulut ke mulut atau ada yang sudah tau produk tersebut akan memesan banyak dan dijual lagi keluar daerah.

Hasil wawancara dengan lembaga pertanian Kecamatan Toroh, keberadaan lembaga yang ada di desa penelitian walaupun sudah membantu dalam proses produksi yang berdampak pada naiknya produktivitas tiap tahun akan tetapi tidak membantu dalam hal perolehan petani karena petani saat datang musim panen langsung menjual ke tengkulak tanpa melalui lembaga apapun yang menaungi sehingga petani hanya sebagai price taker yang berdampak memperlemah daya tawar petani dan akhirnya harga jagung pun tidak bisa maksimal.

\section{Tabel 3. Permasalahan Value Chain Jagung}

\begin{tabular}{ll}
\hline No. & Permasalahan Value Chain Jagung \\
\hline 1 & Menurunnya harga jagung saat musim panen raya \\
2 & Terbatasnya akses pemasaran ke pasar \\
3 & Belum optimal pengolahan produk jagung \\
4 & Produk jagung belum terkoordinasi dalam suatu cluster \\
5 & Kondisi alam yang tidak menentu \\
6 & Kurangnya pengetahuan petani tentang jagung \\
7 & Peran lembaga yang belum optimal \\
\hline
\end{tabular}

Terdapat beberapa permasalahan dalam rantai nilai jagung. Jagung yang merupakan salah satu komoditias pertanian tanaman pangan unggulan kedua setelah padi di Kabupaten Grobogan menjadikan jagung sangat berlimpah. Kecamatan yang menjadi penghasil jagung di Kabupaten Grobogan adalah Kecamatan Toroh, keberadaan jagung yang melimpah menjadikan setiap kali panen raya harga jagung menjadi turun atau lemah karena antara penawaran dan permintaan tidak imbang dengan begitu posisi petani jagung cenderung lemah sehingga hanya bisa sebagai price taker.Permasalah yang ada tidak hanya sebatas harga yang diterima petani yang tidak sesuai karena jumlah jagung yang melimpah saat panen akan tetapi juga pada belum adanya tempat untuk menampung hasil panen jagung seperti bulog sehingga petani saat menjelang masa panen akan langsung menjual jagungnya kepada tengkulak yang sebenarnya apabila ada tempat untuk menampung hasil panen bisa sangat membantu mengontrol harga jagung, selain itu jagung juga salah satu tanaman yang tidak bisa bertahan lama saat disimpan karena apabila jagung sudah dalam bentuk pipilan akan mudah terkena hama yang beresiko merusak jagung untuk mengambalikan jagung ke kondisi semula dibutuhkan biaya yang banyak karena itu perlu tempat penyimpanan dalam hal ini petani tidak memiliki tempat penyimpanan karena tempat penyimpanannya tidak bisa sembarangan untuk menghindari dari hama tersebut harus di bawah dari tempat penyimpanan ada semacam tungku pembakaran baru kemudian tempat penyimpanan tersebut ditaruh di atas tungku tersebut dengan bantuan asap dari tungkulah bisa mencegah hama tersebut selain itu untuk cara alami jagung disimpan dalam bentuk masih utuh dengan kulitnya karena kulit secara alami bisa membantu mempertahankan hama tersebut untuk masuk oleh karena itu hal ini memperparah kondisi petani jagung.

Harga jual jagung sangat tergantung pada tingkat kekeringan jagung, semakin kering jagung maka akan semakin tinggi harganya. Teknik pengeringan jagung bisa dilakukan dengan dua cara pertama yaitu dengan menjemur jagung dalam bentuk pipilan dan jagung dijemur saat masih belum dipanen dibuka kulitnya kemudian dibiarkan kering sendiri, kedua cara ini memiliki keterbatasan masing - masing. Petani pada umumnya memilki keterbatasa dalam kepemilikan lahan sehingga petani tidak bisa melakukan penjemuran sampai pada kadar air yang dibutuhkan sehinga harga jagung tidak bisa maksimal, selain itu untuk teknik 
pengeringan saat masih belum dipanen membutuhkan cahaya matahari yang optimal sehingga apabila tidak ada matahari membutuhkan waktu ekstra untuk jagung mencapai kadar air yang dibutuhkan akan tetapi, cara ini petani masih banyak yang belum tahu. Tingkat kadar air jagung juga menjadi langkah awal untuk menjaga kualitas jagung saat disimpan karena seperti penjelasan sebelumnya kadar air juga mempengaruhi hama yang menyerang, dengan begitu pengetahuan petani tentang jagung harus lebih ditingkatkan. Kondisi alam ikut mengambil peran dalam pertanian jagung karena seperti pada umumnya tanaman jagung juga membutuhkan kondisi ideal untuk bisa tumbuh jagung tidak bisa terlalu banyak air maupun sedikit air walaupun pada dasarnya jagung tanaman yang kuat terhadap cuaca akan tetapi untuk usia tertentu jagung membutuhkan kondisi alam yang sesuai, selain dalam proses produksi kondisi cuaca juga mempengaruhi dalam proses penjemuran, selain ituharga jagung yang rendah juga dikarenakan petani tidak tahu kondisi pasar, terbatasnya informasi petani tentang kondisi pasar membuat daya tawar petani kurang apabila sudah memiliki wadah akan mempermudah akses tersebut sehingga perlu adanya cluster dalam hal ini, yang dimaksud cluster adalah daerah pusat hasil jagung sehingga bisa terfokus yang mana sudah terjadi kerjasama yang bagus dengan begitu akan lebih efektif dan efisien.

Palaku yang berperan dalam pertanian jagung tidak hanya sebatas pada petani yang berperan dalam proses produksi yang mengalami berbagai macam dari masa tanam hingga panen sehingga harga yang diterima petani tidak sesuai, akan tetapi ada juga pelaku lain yang ikut berperan yaitu pengolah. Kabupaten Grobogan sudah mulai membuat berbagai macam program untuk memajukan hasil pertanian khususnya jagung salah satunya dengan membuat hasil olahan jagung. Pada proses pengolahan jagung terdapat beberapa permasalahan, walaupun sudah dilakukan pelatihan yang dilakukan dinas BKP (Badan Keatahanan Pangan) Kabupaten Grobogan untuk pembuatan hasil olahan jagung akan tetapiberdasarkan hasil wawancara dengan Wakil Kepala dinas BKP di Kabupaten Grobogan minat untuk membuat olahan masih sangat kecil sehingga usaha pengolahan jagung masih sedikit dan berpencar di beberapa wilayah di Kabupaten Grobogan salah satu kecamatan yang memiliki pengolah jagung adalah Kecamatan Toroh akan tetapi skala usaha pengolah jagung di Kecamatan Toroh masih pada tingkatan home industrydan hanya terdapat satu pengolah saja. Pengolahan jagung apabila bisa lebih ditingkatkan dengan terus diadakannya pelatihan dan promosi produk akan sangat membantu, petani bisa ikut serta mengikuti program tersebut sehingga bisa memberikan kemampuan tambahan untuk petanimengolah jagung dengan begitu bisa memberikan nilai tambahpada jagung dan memberikan keuntungan ekonomi baik jagung yang dijual dalam bentuk jagung segar ataupun jagung yang dijual dalam bentuk olahan. Permasalahan lainnya dalam rantai nilai jagung adalah lembaga yang ikut andil dalam rantai nilai perannya masih belum optimal mulai dari keberadaan kelompok tani yang masih belum bisa memberikan manfaat pada anggotanya sekain itu petugas yang membantu dalam proses produksi hingga panen jagung diwakili oleh PPL jumlah masih kurang memadai sehingga petani jagung di Kecamatan Toroh kurang bisa maksimal dalam menerima informasi tentang jagung sehingga berdampak pengetahuan petani menjadi kurang, selain itu lembaga yang berperan masih belum bisa memberikan bantuan dalam hal peningkatan harga jual jagung.

Hasil dari proses wawancara secara In Deep Interview dengan para key - person (A$\mathrm{B}-\mathrm{G}-\mathrm{C})$ ditemukan beberapa strategi untuk mengatasi permasalahan value chain jagung seperti yang tertera pada tabel 4. 
Eka Widayat Julianto Dan Darwanto: Analisis Rantai Nilai (Value Chain) Jagung Di Kecamatan Toroh Kabupaten Grobogan

Tabel 4. Strategi Value Chain Jagung

\begin{tabular}{ll}
\hline No. & Strategi Value Chain Jagung \\
\hline $\mathbf{1}$ & Pendirian koperasi untuk menampung produksi jagung dan sekaligus \\
& melakukan pemasaran sehingga tidak adanya ketergantungan pada pengepul \\
$\mathbf{2}$ & Penambahan tenaga penyuluh \\
$\mathbf{3}$ & Pemberian bantuan modal kerja dan bantuan dalam segi pengolahan jagung \\
$\mathbf{4}$ & Pembekalan pengetahuan yang cukup mengenai teknik penanaman, \\
& perawatan, pengolahan, penyimpanan \\
\hline
\end{tabular}

Strategi untuk mengatasi permasalahan yang dihadapi dalam agribisinis jagung adalah, pertama, pendirian koperasi atau yang seperti lumbung desa peran lumbung desa tersebut sebagai wadah penyimpanan juga sebagai tempat transaksi bagi petani dan pembel, jadi hasil panen akan disimpan dilumbung desa tersebut, dengan teknik penyimpanan yang benar berdasarkan hasil wawancara yang mana dalam lumbung tersebut bagian bawah dibuat seperti tungku kemudian jagung ditaruh di atas tungku tersebut dengan begitu jagung akan diasapi dengan asap tersebut jagung akan terhindar dari hama bubuk sehingga kualitas jagung terjaga, baru kemudian setelah ada pembeli dan harga stabil jagung bisa dijual dengan begitu akanada kontrol harga baik yang diterima petani maupun yang harus dibayarkan oleh pembeli. Kemudian, perlu adanya penambahan tenaga penyuluh baik dari Dinas Pertanian Kabupaten Grobogan maupun dinas BKP sehingga adanya pemerataan penanganandengan begitu para petani mendapatkanpengetahuan tentang bertani yang cukupdan memiliki pengetahuan dan skill untuk melakukan pengolahan jagung sehingga bisa memberikan tambahan nilai ekonomi untuk petani selain sebagai petani juga bisa sebagai pengolah. Petani diberikan bantuan secara optimal baik dari sisi modal dan pemerintah ikut memasarkan produk, pemberian peralatan penunjang. Petani tidak akan kerepotan mencari dana apabila hasil panen kurang maksimal. Perlunya sosialisasi dan pembekalan pengetahuan mengenai teknik penanaman, perawatan, pengolahan, penyimpanan akan bisa mempengaruhi dari hasil panen serta harga jual jagung.

\section{SIMPULAN}

Kesimpulan yang dapat diambil dalam penelitian ini adalah: (1) Alur rantai nilai jagung terbagi menjadi dua yaitu:Jagung segar:Petani - tengkulak/ pedagang kecamatan pengepul besar konsumen, Petani - tengkulak/ pedagang kecamatan - pedagang kecil konsumen; Jagung olahan:Petani - pedagang kecil - pengolah - konsumen, Petani - pengolah - konsumen; (2) Analisis rantai nilai jagung segar pihak yang diuntungkan yaitu tengkulak karena memperoleh margin pemasaran lebih banyak diantara petani dan pengepul besar sedangkan untuk jagung olahan yang memperoleh margin terbesar adalah pengolah; (3) Hasil dari perhitungan analisis rantai nilai jagung segar dengan melihat profit dari harga jual per $\mathrm{kg}$ pelaku yang cenderung diuntungkan adalah tengkulak dengan keuntungan per kg adalah $\mathrm{Rp}$ 400,00 hal ini karena tengkulak dari kepemilikan lahan untuk menjemur sudah ada selain itu tengkulak juga memiliki fasilitas penyimpanan dan untuk informasi pasar tengkulak lebih menguasai, sedangkan untuk jagung olahan pihak yang paling diuntungkan adalah pengolah dari harga jual jagung olahan yang paling tinggi yaitu pengolah dengan keuntungan per $\mathrm{kg} \mathrm{Rp}$ $7.065,00$, profit yang diterima pengolah lebih besar wajar karena pengolah memberikan nilai tambah pada jagung dengan menjual jagung dalam bentuk makanan olahan salah satunya adalah beras jagung; (4) Berdasarkan hasil perhitungan R/C Ratio setiap pelaku sudah mendapatkan keuntungan sehingga layak untuk tetap menjadi pelaku tersebut,akan tetapi petani dalam hal ini walaupun $\mathrm{R} / \mathrm{C}$ menunjukan sudah mendapatkan keuntungan sebenarnya masih mengalami masalah sehingga hasilnya sebenarnya masih bisa ditingkatkan; (5) Keberadaan lembaga yang menunjang dalam hal ini kelompok tani, PPL, BKP tidak terlalu 
memberikan efek dalam penerimaan petani karena saat musim panen petani langsung melakukan transaksi dengan pembeli tanpa campur tangan dari lembaga sehingga membuat harga cenderung lemah, sedangkan untuk keberadaan dari pengolah yang dibina oleh BKP juga kurang bisa memasarkan karena selama ini masih menggunakan pemasaran mulut ke mulut.

\section{DAFTAR PUSTAKA}

Arsyad, Lincolin. 1993. Metode Penelitian Untuk Ekonomi dan Bisnis. Yogyakarta: UPP AMP YKPN.

Badan Pusat Statistik. 2014. Kabupaten Grobogan Dalam Angka 2009-2013. Jawa Tengah.

Campbell, R. 2008. Kerangka Kerja Rantai Competitiveness at The FRONTERR. Majalah Kerjasama Megister Manajemen Fakultas Ekonomi Universitas Udayana, USAID dan SENANDA. (Juli)

Dinas Pertanian Kabupaten Grobogan. 2014. Kabupaten Grobogan.

Dzanjal, Joseph, Prince Kapondangaga dan Hardwick Tchale. 2013. Value Chain Analysis of Beef Central and Southern Malawi (Case Studies of Lilongwe and Chikhwawa District). International Jurnal of Business Social Science. 4 (6)

Full Bright Consultancy. 2008. Final Report Ministry of Agriculture and Coorporatives Departement of Agriculture. Nepal.

Irianto, Heru dan Emy Widiyanti. 2013. Analisis Value Chain Efisiensi Pemasaran Agribisnis Jamur Kuping di Kabupaten Karanganyar. Penelitian Kerjasama LPPM UNS dengan Bank Indonesia Solo. 9 (2).

Kotler, Philip. 1993. Manajemen Pemasaran. Jakarta: Erlangga . 2002. Manajemen Pemasaran (Jilid 2). Jakarta: PT. Ikrar Mandiri.

Monzery, Hedron Asfira, Shorea Khaswarina dan Novia Dewi. 2014. Analisis Rantai Nilai Agroindustri Susu Bubuk Kedelai (Studi Kasus Industri Sumber Gizi Nabati dan Melilea di Kota Pekanbaru). Jurnal Agribisnis.13 (1): 29 -32.

Nawawi, Hadari. 2001. Manajemen Sumber Daya Manusia. Jakarta: Bumi Aksara

Nurmala, Tati. Suyono, Aisyah D. Rodjak, Abdul. Suganda, Tarkus, Natasasmita, Sadeli. Simarmata, Tualar, Salim, E. Hidayat. Yuwariah, Yuyun. Sendjaja, Tuhpawana Priyatna. Wiyono, Sulistyodewi Nur Dan Hasani, Sofiya. 2012. Pengantar Ilmu Pertanian. Yogyakarta: Graham Ilmu.

Olukunle, Oni Timothy. 2013. Evaluation of Income and Employment Generation from Cassava Value Chain In Nigerian Agriculture Sector. Asian Jurnal of Agriculture and Rural Development. 3 (3):79-92.

Peraturan Menteri Pertanian nomor 273/kpts/OT.160/4/2007 Tentang Pedoman Pembinaan Kelembagaan Petani.

Pearce dan Robinson. 2008. Manajemen Strategis. Jakarta: Salemba Empat.

Porter, Michael E.1985. Competitive Advantage: Creating and Sustaining Superior Performance. New York: Macmilan.

Rejeki, Sri. 2006. Analisis Efisiensi Usaha Tani Jahe di Kabupaten Boyolali (Studi Kasus Kecamatan Ampel). Tesis. Semarang: Universitas Diponegoro

Rheza, Boedi dan Elizabeth Karlinda. 2013. Analisis Rantai Nilai Usaha Kakao di Kabupaten Majene. Laporan Penelitian Ford Foundation dengan Komite Pemantauan Pelaksanaan Otonomi Daerah. Jakarta Selatan.

Sewando, Ponsian T. 2012. Urban Marked - Linked Cassava Value Chain in Morogoro Rural District, Tanzania. Jurnal Of Sustainable Development in Africa. 14 (3). 
Eka Widayat Julianto Dan Darwanto: Analisis Rantai Nilai (Value Chain) Jagung Di Kecamatan Toroh Kabupaten Grobogan

Sukayana, I Made, Dwi Putra Darmawan dan Ni Putu Udayani Wijayanti. 2013. Rantai Nilai Komoditas Kentang Granola di Desa Candikuning Kecamatan Batuti Kabupaten Tabanan. Jurnal Agrobisnis dan Agrowisata. 2 (3).

Swastha Basu dan Irawan.1990. Manajemen Pemasaran Modern. Yogyakarta: Liberty.

Tarigan, Rina Juliana, Dwi Putra Darmawan dan I Gede Setiawan Adi Putra. 2013. Manajemen Rantai Nilai Jeruk Madu di Desa Barus Jahe Kabupaten Karo Sumatra Utara. Jurnal Agribisnis dan Agrowisata. 2(4).

Undang - Undang Nomor 16 Tahun 2006 Tentang Sistem Penyuluhan Pertanian, Perikanan, dan Kehutanan.

Wahyuni, Sri. 2003. Kinerja Kelompok Tani Dalam Sistem Usaha Tani Padi Dan Metode Pemberdayaan. Jurnal Litbang Pertanian, 22(1).

Warisno. 1998. Budi daya Jagung Hibrida. Yogyakarta: Kanisius.

Zakaria, Wan Abbas. 2003. Pengetahuan Kelembagaan Petani: Kunci Kesejahteraan Petani. Bandar Lampung: Fakultas Pertanian Universitas Lampung. 
Jurnal Penelitian Ekonomi dan Bisnis (JPEB), 1 (1), 2016, Hal: 1 - 15 